\title{
Research of Exhaust Emissions by Chainsaws with the use of a Portable Emission Measurement System
}

Vasiliki Dimou $^{1^{*}}$, Apostolos Kantartzis ${ }^{2 *}$, Chrisovalantis Malesios ${ }^{3,4}$ and Emmanouil Kasampalis $^{5^{*}}$

${ }^{1}$ Laboratory of Forest Technology, ${ }^{2}$ Laboratory of Forest Engineering Sciences and Surveying, "Democritus University of Thrace, Department of Forestry and Management of the Environment and Natural Resources, 193 Pandazidou Orestiada, PC 68200, Greece ${ }^{3}$ Department of the Environment, University of the Aegean, Mytilene PC 81100, Greece,

${ }^{4}$ Aston Business School, Aston University, Birmingham PC B4 7ET, UK, vdimou@fmenr.duth.gr ${ }^{1}$, apkantar@fmenr.duth.gr ${ }^{2}, \underline{\text { malesios@env.aegean.gr }}{ }^{3}$, c.malesios@aston.ac.uk ${ }^{4}$, manoliskas98@gmail.com ${ }^{5}$

\begin{abstract}
Anthropogenic activities in the environment have an impact on climate change. Among these activities is the use of the chainsaw which plays an important role through releasing greenhouse gas emissions in the atmosphere. Hence the need for research on improved logging operations is of importance. The present study compares carbon monoxide $(\mathrm{CO})$ and nitrogen dioxide $\left(\mathrm{NO}_{2}\right)$ emissions generated by the engines of one catalytic chainsaw and two conventional chainsaws, of which one is professional and the other amateur. Measurements were carried out under three functional modes (infrequent accelerator use, use of quality oils, use of clean filters). Measurements that were conducted under normal conditions were named 'witness measurements' and were used for future comparisons. Additionally, a set of measurements for $\mathrm{CO}$ and $\mathrm{NO}_{2}$ emissions was collected under different operation modes for all three types of saws (frequent accelerator use, use of low quality oils, use of impure filters). Data collection was carried out in real conditions using a portable gas detector. Average concentration values of $\mathrm{CO}$ and $\mathrm{NO}_{2}$ under normal conditions for all three types of chainsaw found in the air of the operator's breathing zone were $88.32 \mathrm{ppm}$ and $0.07 \mathrm{ppm}$ respectively. Results show that $\mathrm{CO}$ concentrations exceed the permissible exposure limit (50 ppm), whereas $\mathrm{CO}$ concentrations in excess of the short-term exposure limit (300 ppm) were only found in the case of the amateur chainsaw operated with low quality oils. These results are of use towards efforts to reduce the $\mathrm{CO}$ and $\mathrm{NO}_{2}$ to the atmosphere.
\end{abstract}

Keywords: $\mathrm{CO}, \mathrm{NO}_{2}$, greenhouse gasses, $T L V$ 


\section{Introduction}

In a work environment, low air quality due to hazardous emissions is one of the elements which puts employees at high risk for illnesses through long-term occupational exposure (Leszczyn்ski 2014). In addition, exhaust emissions of logging affects the environment and has major impacts on climate change. Climate change is caused by the excessive levels of greenhouse gasses especially carbon, in the atmosphere (Lijewski et al. 2013). Climate change has presented new challenges in forest management (Keenan \& Nitschke 2016). Logging operations emit greenhouse gasses, hence creating a need for research on improved logging operations.

Merkisz et al. (2010) report that tests under actual operating conditions are one of the most rigorous for measuring exhaust emissions generated by internal combustion engines. In this way the operating conditions of the engine are taken thoroughly into consideration (Lijewski et al. 2013). Additionally, the conditions of the microenvironment in which a chainsaw is operating and which are constantly changing can also be taken into consideration.

In this study exhaust emission measurements were performed while the chainsaw operator was working under real conditions. Furthermore, scientific research centers or legislative bodies consider introducing the on-road exhaust emission testing of homologation procedures (Walsh 2011).

CO, hydrocarbons and nitric oxides constitute about 10\% (6.2 and 1\% respectively) of chainsaw exhaust that are considered to be harmful to man. The remaining $90 \%$ including nitrogen $\left(\mathrm{N}_{2}\right)$, oxygen $\left(\mathrm{O}_{2}\right)$, carbon dioxide $\left(\mathrm{CO}_{2}\right)$ and water $\left(\mathrm{H}_{2} \mathrm{O}\right)$ are not considered hazardous (Wójcik 2006).

Incomplete combustion of the engines leads to the creation of air pollutants and particles. Two of the polluting combustion gases are $\mathrm{CO}$ as well as $\mathrm{NO}_{2}$. $\mathrm{CO}$ is a colorless, odorless, and toxic gas used in numerous branches of industry or is produced in the form of waste product. $\mathrm{CO}$ poisoning symptoms depend on its concentration in the air, the period of activity and a person's work intensity. Shortterm exposures to concentrations of over $2181.5 \mathrm{ppm}$ result in fainting and - in case of no fresh air (oxygen) access - death within just a few minutes, due to brain hypoxia (Ruth-Sahd et al. 2011).

In silviculture, $\mathrm{CO}$ is emitted by petrol powered internal combustion engines such as heating devices at seed husking plants and retort furnaces used for wood coal 
production. Exhaust emissions are frequently the topic of studies investigating the impact of timber harvesting on the environment (Athanassiadis 2000). In a study by Lijewski et al. (2013) it was found that emissions generated by two-stroke chainsaw machines are ten times higher than those produced by other forest machinery such as harvesters and forwarders. However, their concentrations in the forest environment are quite low and do not exceed permissible exposure limits (Magagnotti et al. 2014; Slaughter et al. 2004; Sowa et al. 2005).

The other harmful gas produced by two-stroke chainsaw engines is $\mathrm{NO}_{2}$. Nitrogen monoxide (NO) at temperatures, higher than $1000^{\circ} \mathrm{C}$ (as in internal combustion engines), is converted into $\mathrm{NO}_{2}$ and is part of the major pollutants produced by two-stroke internal combustion engines such as chainsaw motors (other pollutants of two-stroke engines include $\mathrm{HC}, \mathrm{CO}, \mathrm{CO}_{2}$ and particles) (Gentekakis 2003). Experiments on animals that were exposed to high concentrations of nitrogen oxides $\left(\mathrm{NO}_{\mathrm{x}}\right)$, showed both reversible and irreversible injury to the lungs as well as biochemical changes. Lower concentrations, with more prolonged durations of exposure, led to tissue damage, obstruction of bronchioles and great susceptibility to microbial inflammations of the respiratory system. In conclusion, higher oxide concentrations are more detrimental to human and animal health compared with prolonged exposure to lower concentrations (World Bank Group, 1998). Out of the seven $\mathrm{NO}_{\mathrm{x}}$, three $\left(\mathrm{N}_{2} \mathrm{O}, \mathrm{NO}, \mathrm{NO}_{2}\right)$ can be found in the atmosphere in high concentrations of which only $\mathrm{NO}$ and $\mathrm{NO}_{2}$ are toxic.

\section{Aim of this research}

This study constitutes the second part of a research project investigating the impact of chainsaw emissions on the environment and climate change. In detail:

1. The measurement of short-term concentrations of $\mathrm{CO}$ and $\mathrm{NO}_{2}$ is the $2^{\text {nd }}$ part of the project and aim of the current paper.

2. The measurement of short-term concentrations of $\mathrm{NO}$ and methane $(\mathrm{CH} 4)$ is the $1^{\text {st }}$ part of the project (Dimou et al., 2018).

3. These measurements were carried out to investigate the use of chainsaws for part-time at farm or urban green space maintenance and their impacts on the environment. 


\section{Materials and methods}

All measurements were collected under field conditions with the help of an analyzer for the monitoring of exhaust pollutants (Dräger X-am 5000) emitted by three chainsaws, namely a professional, a catalytic and an amateur. The exhaust gas analyzer was portable and attached in the chainsaw operator's belt. Measurements concerned $\mathrm{CO}$ and $\mathrm{NO}_{2}$ concentrations in the breathing zone of the chainsaw operator. The three chainsaws that were used in the study were: a) a professional Stihl $361 \mathrm{MS}$, b) an amateur Stihl 170 MS and c) a catalytic Stihl 170D (see Table 1 for the characteristics of the three chainsaws). The term 'breathing zone' refers to the $30 \mathrm{~cm}$ area immediately surrounding the operator's mouth and nose (Ojima 2012; Leszczynnski 2014). The measured values have been compared to the Threshold limit value (TLV).

\section{Table 1}

Measurements were carried out for all three chainsaws under normal conditions, i.e. with a regular to infrequent accelerator use, with good quality oils (recommended and manufactured by a well-known company) and with clean filters. These were benchmark measurements, used for future comparisons, and were named witness measurements. Subsequently, for each of the three chainsaws separate measurements of $\mathrm{CO}$ and $\mathrm{NO}_{2}$ emissions were performed with $\mathrm{X}_{2}^{\prime}=$ frequent accelerator use, $X_{3}^{\prime}=$ use of poor quality oils and $X^{\prime}{ }_{4}=$ impure filter, while the other conditions remained normal (for $\mathrm{X}_{2}{ }_{2}=$ use of good quality oils and clean filter, for $\mathrm{X}_{3}{ }_{3}=$ clean filter and infrequent use of accelerator and for $\mathrm{X}^{\prime}{ }_{4}=$ good quality oils and infrequent use of accelerator). The petrol that was used for the chainsaws was regular unleaded with an octane number of 98 .

Table 2 shows the chainsaw types that were used: $X_{1}=$ professional chainsaw, $\mathrm{X}_{2}=$ catalytic chainsaw and $\mathrm{X}_{3}=$ amateur chainsaw, as well the operating parameters: $X_{1}{ }_{1}=$ normal conditions, $X_{2}{ }_{2}=$ frequent accelerator use, $X_{3}{ }_{3}=$ poor quality oils, and $X^{\prime} 4=$ impure filter. These conditions were repeated once for measurements $\mathrm{Y}_{1}=\mathrm{CO}$, and a second time for measurements $\mathrm{Y}_{2}=\mathrm{NO}_{2}$. In total, 1699 measurements were carried out, of which 755 were for $\mathrm{CO}$ and another 892 for $\mathrm{NO}_{2}$ emissions. Measurements were made in ppm (one part per million by volume in air $-\mathrm{ml} / \mathrm{m}^{3}$ ). 
Measurements of $\mathrm{CO}$ and $\mathrm{NO}_{2}$ gases have been taken during the cross-cutting operations of Quercus petraea in an exposed yard (Figure 1). Measurements of both $\mathrm{CO}$ and $\mathrm{NO}_{2}$ were taken simultaneously from the analyzer. Different operating parameters per day have been applied separately for each chainsaw. Hence, gas measurements for each type of chainsaw were completed in four days. Overall, the total measurements, i.e. for each type of chainsaw and each operating parameter, were collected within a duration of 12 days. The measurements were collected on-line in the exhaust gas analyzer with the capability at the end of each experimental effort (i.e. by measuring each type of chainsaw and operating parameters), the measurement data to be transferred to a computer. Data were collected at the beginning of September 2018 at a mean temperature of $\mathrm{T}_{\text {mean }}=23.6{ }^{0} \mathrm{C}$ while the minimum and maximum temperatures were respectively $\mathrm{TN}=17.2^{\circ} \mathrm{C}$ and $\mathrm{TX}=28.4^{\circ} \mathrm{C}(\mathrm{HNMS} 2018)$, whereas longevity prevailed throughout the data collection period. Fuel wood has remained in the exposed yard throughout the summer and was dry with a moisture content of around $15 \%$. The fuel wood was approximately $1.30-1.50 \mathrm{~m}$ in length and $20-30 \mathrm{~cm}$ thick. Cross cutting was made at a length size of $20-25 \mathrm{~cm}$. The total amount of wood that was cut was $24 \mathrm{~m}^{3}$.

\section{Figure 1}

\section{Table 2}

A statistical modeling approach was used to examine the potential effects of the chainsaw type and operation type on the concentrations of $\mathrm{CO}$ and $\mathrm{NO}_{2}$ as they were measured during the field conditions. Specifically, analysis of variance (ANOVA) (Dobson and Barnett 2008) was chosen as the most suitable approach for linking $\mathrm{CO}$ concentrations with the two factors under investigation. However, concentrations of $\mathrm{NO}_{2}$ comprise a non-Gaussian distributed dataset including a large number of zero values, hence making it not suitable for applying ANOVA. To respect the nature of the specific dataset, a zero inflated Gaussian regression modeling was applied (see, e.g., Lambert 1992; Malesios et al. 2014) to link the former factors of chainsaw and operation type to the $\mathrm{NO}_{2}$ concentrations. In the following sub-sections, the representations of the implemented statistical methods are analytically presented. 
Two - way analysis of variance

In order to examine the hypothesis that concentrations of $\mathrm{CO}$ are dependent on the chainsaw and operation type, two - way ANOVA was implemented. Let $a_{i}$ be the grouping variable which corresponds to the factor of chainsaw type with $I$ levels $(I=$ 3 ) and $\beta_{j}$ the second independent variable which denotes the operation type with $J$ levels $(J=4)$, then the two - way ANOVA can be written in generalized linear model form as (Dobson and Barnett 2008):

$$
\begin{aligned}
& y_{i j k}=\mu+a_{i}+\beta_{j}+\varepsilon_{i j k} \\
& i=1, \ldots I, j=1, \ldots, J, k=1, \ldots, n_{i j}
\end{aligned}
$$

where $y_{i j k}$ denotes the values of the dependent variable, $\mu$ the overall mean of $y_{i j k}$ and $\varepsilon_{i j k}$ the error term. The total sample size is $n_{i j}\left(n_{i j}=755\right)$.

The appropriate criterion which is used in order to test if there are differences concerning the dependent variable for each level of independent(s) is the $F-$ test. The hypotheses which are tested assuming the first model are the following:

$$
\begin{aligned}
& H_{0}: \alpha_{1}=\ldots=\alpha_{I} \\
& H_{0}: \beta_{1}=\ldots=\beta_{J}
\end{aligned}
$$

\section{Zero-inflated regression modeling}

If $y_{i k}$ denotes the $i-t h$ response of the $k-t h$ independent variable of concentration measurements of $\mathrm{NO}_{2}(i=1,2, \ldots, 892 ; k=1,2)$ and that $\mathbf{x}^{T}$ denotes the $(2 \times 892)$ matrix comprising of the values of the independent variables, then the regression-type zero inflated model fitted to the raw data of $\mathrm{NO}_{2}$ values is described by the following equation:

$$
\begin{aligned}
& y_{i k} \sim N\left(\mu_{i k}, \sigma^{2}\right), \quad e_{i k} \sim N\left(0, \sigma^{2}\right) \\
& \mu_{i k}=\mathbf{X}^{t} \cdot \boldsymbol{\beta}
\end{aligned}
$$

where $\mu_{i k}$ and $\sigma^{2}$ are the mean and variance of the dependent variables under a Gaussian distribution. Finally, $\boldsymbol{\beta}=\left(\beta_{1}, \beta_{2}, \ldots, \beta_{k}\right)^{t}$ are the regression coefficients of the predictors, where $\beta_{1}$ denotes the constant term and $\beta_{2}, \ldots, \beta_{k}$ are the coefficients for the various levels of the two factors under investigation $(k=1,2, \ldots, 5)$. 


\section{Results}

\section{Descriptive statistics}

Table 3 below presents the descriptive statistics of $\mathrm{CO}$ and $\mathrm{NO}_{2}$ concentration values in the overall data. The average CO concentration is $135.55 \mathrm{ppm}$, whereas the average $\mathrm{NO}_{2}$ concentration is $7.09 \mathrm{ppm}$. However, it is also observed that the measurements are extremely variable, as the standard deviation of the data is quite large (184.31 ppm and $35.13 \mathrm{ppm}$ for $\mathrm{CO}$ and $\mathrm{NO}_{2}$ concentrations, respectively).

Descriptive statistics for the data, broken down by the two factors of chainsaw and operation type are presented in Table A1 in the Appendix.

\section{Table 3}

There are important differences in the average levels of the two pollutant substances, however it is not easily identifiable if these large differences are due to systematic variation in the levels of operation and chainsaw type or due to extreme values. Subsequent analyses, attempt to answer this question, by use of statistical inference in the form of regression-type modeling such as the two-way analysis of variance and the zero-inflated regression.

The concentrations of $\mathrm{CO}$ in the breathing areas of workers during logging operations are summarized (Figure A1 Appendix). The concentration values are skewed, so the values were log-transformed to normalize their distribution (see Figure A2). Logarithmic transformation of the $\mathrm{CO}$ concentration values results in the normalization of the latter values, as is seen from inspection of Figure A2.

Figure A3 in the Appendix shows the $\mathrm{CO}$ concentrations broken down by the type of chainsaw. The $\mathrm{CO}$ values measured with the amateur chainsaw are more concentrated around zero when compared to the catalyst and professional chainsaws. In figure A4 the average $\mathrm{CO}$ concentrations in terms of type of operation are shown.

The following bar charts (Figure 2) present the average $\log (\mathrm{CO}$ ) concentrations in terms of the various levels of chainsaw type and operation type.

\section{Figure 2}


Tables 3 to 6 show the results of the two-way analysis of variance, in the form of post-hoc tests. Specifically, the Scheffe, LSD and Bonferroni tests results are included, in the form of mean differences between the various categories, corresponding p-values and $95 \%$ confidence intervals.

Table 4 shows the post-hoc test results regarding the factor of chainsaw type. That the only statistically significant difference in the levels of the $\log (\mathrm{CO})$ concentrations is between the catalyst and the amateur chainsaws, with those measured via the catalyst chainsaw showing increased levels of the pollutant. According to the Scheffe test, mean difference between the catalyst and amateur chainsaws is 0.249 , with a corresponding $p$-value $=0.043<0.05$, indicating that the difference is statistically significant at the $5 \%$ significance level (the $95 \%$ confidence interval of the difference is 0.006-0.494).

\section{Table 4}

These results are summarized in Table A2 in the Appendix, where the two subsets are distinguishing the levels of $\mathrm{CO}$ between the values of amateur and catalyst chainsaws. Table 5 shows the post-hoc test results relating to the other factor of operation type. Although the results are showing small differences between the three tests, the main outcome is that the type of oil is statistically different from all other three operation types with regard to the $\mathrm{CO}$ concentrations. Oil concentrations are higher when compared to the other three types of operation. For a summary of the post-hoc differentiation results, see Table A3 in the Appendix.

\section{Table 5}

Next, the effects of operation and chainsaw type on the concentration levels of $\mathrm{NO}_{2}$ are investigated. Figure $\mathrm{A} 5$ in the Appendix, shows the concentrations of $\mathrm{NO}_{2}$ and log-transformed $\mathrm{NO}_{2}$. The data comprise of many excess zero values, making it extremely difficult to transform the data for the residuals of $\mathrm{NO}_{2}$ to be normally distributed, an assumption required for the robustness and validity of analysis of variance method. 
To perform an analysis on the particular dataset it is crucial to respect the nature of the data, i.e. the inclusion of excess zeros along with the non-normality of the observations. In order to do this, a zero inflated Gaussian regression model linking the former values to the two factors of operation and chainsaw type was applied to the $\mathrm{NO}_{2}$ concentrations.

The following bar charts (see Figure 3) present the average $\mathrm{NO}_{2}$ concentrations by the various levels of chainsaw and operation type. The figures based on the raw data indicate that in terms of chainsaw type, the catalyst chainsaw produced the highest levels of $\mathrm{NO}_{2}$ concentrations, whereas the descriptive results of average concentrations show that the filter type has produced extremely high values of $\mathrm{NO}_{2}$.

\section{Figure 3}

To generalize these descriptive results, a regression-type modeling based on the zero inflated Gaussian distribution for the response variable of $\mathrm{NO}_{2}$ concentrations was applied. The results of a regression-type modeling approach are presented below, where the response is assumed to follow a zero-inflated (semi-) continuous distribution.

Specifically, Table 6 presents the results of median parameter estimates for the independent factors obtained by the fit of the zero inflated Gaussian regression model, along with the corresponding significances in the form of $p$-values.

\section{Table 6}

Parameter estimates indicate that both factors are statistically significant predictors of $\mathrm{NO}_{2}$. The results of parameter estimates indicate that for the different levels of the covariate of chainsaw type, it is observed that under the catalyst chainsaw, concentration measurements of $\mathrm{NO}_{2}$ are higher, in comparison to the other two types of chainsaws used $(b=121.9$, $\mathrm{p}$-value $<0.05)$. There are also statistically significant differences among the various types of operations with regard to $\mathrm{NO}_{2}$ concentrations. According to the results of Table 6 , the $\mathrm{NO}_{2}$ concentrations are higher for the filter operation type in comparison to all other operations (i.e. witness, frequent acceleration and oil), since all operation type parameters are negative and 
statistically significant in comparison to the reference level category of filter ( $\mathrm{p}$ value $<0.001$ ), indicating that their operation reduces the $\mathrm{NO}_{2}$ concentrations.

The visual representation concerning the interaction between the concentrations of $\mathrm{CO}$ for operation and chainsaw type, depicted in Figure 4b, assists in the interpretations of our results. Measurements collected by the oil operation type are always higher, independent of the chainsaw type used. The acceleration operation type is shown to be dependent on the chainsaw type, as the $\mathrm{CO}$ concentrations are significantly decreasing when using an amateur chainsaw versus a catalyst. This is also true when using the witness operation type. The catalyst chainsaw used in the acceleration operation has significant problems, in terms of the $\mathrm{CO}$ concentrations, since the combination of catalyst chainsaw with an acceleration operation produces the highest $\mathrm{CO}$ concentrations.

\section{Figure 4 a,b}

As it is illustrated in Figure 4a, CO emissions for the professional and catalytic chainsaw for the three operating parameters (frequent accelerator use, use of poor quality of oils and impure filter) are below the TLV. This value is slightly exceeded (301.12 ppm) in the case of the amateur saw when used with low quality oils. The results show excess of Permissible Exposure Limit (50 ppm) or, the time weighted average permissible exposure limit, which is also seen in the study by Sowa and Leszczyṅski (2014).

\section{Figure 5 a,b}

Figure $5 \mathrm{~b}$ compares the concentration levels of $\mathrm{NO}_{2}$ considering the interaction effects of both operation type and type of chainsaw.

All three types of chainsaw seem to be affected similarly by the operation type, in terms of the $\mathrm{NO}_{2}$ pollution concentrations. In general, the filter operation type increases the concentration levels for all three types of chainsaw. The catalytic chainsaw, as seen in Figure 5b, causes higher $\mathrm{NO}_{2}$ concentrations in all cases under investigation. Note that for $\mathrm{NO}_{2}$ the threshold limit values are $5 \mathrm{ppm}$ for 8-hour daily work and short-term exposure (Figure 5a). $\mathrm{NO}_{2}$ emissions are below the TLV for all 
chainsaw types (professional, catalytic, amateur) and the three different functional modes (frequent accelerator use, low quality oils and impure filters) (Figure 5a).

\section{Discussion}

Pollutants emitted by chainsaws during forest operations and logging can cause deterioration of the natural environment by adding to the greenhouse effect and enhancing health hazards (Athanassiadis 2000).

The study of exhaust emissions produced by forestry machinery shows that $\mathrm{CO}$ emission is 10 times higher in the case of two-stroke chainsaws than in the case of harvesters or forwarders (Lijewski 2013).

The exposure limits for harmful or hazardous substances in the air have been defined in employment protection regulations (Leszczyniski 2014). Greek regulations, set by the Hellenic Institute for Occupational Health and Safety, concerning threshold limit values for chemical substances specify that the $\mathrm{CO}$ permissible exposure limit must not be higher than $50 \mathrm{ppm}$ in the case of the 8-h time-weighted average permissible exposure limit (TWAEL) and $300 \mathrm{ppm}$ in the case of the 15-min shortterm exposure limit (STEL). Exceeding the 15-minute short-term exposure limit must not occur more frequently than twice per work shift or once every hour (Leszczyṅski 2014)

Threshold limit value is determined in Greece by two Presidential Decrees (P.D. 338/2001 and P.D. 339/2001), which define it as the limit of an employee's exposure to a chemical agent, measured in the air of his/her breathing zone, that should not be exceeded during any kind of 8-hour daily work and forty-hour weekly work (Daikou \& Dontas 2013). The current TLV is listed at 300ppm.

Another recent major development in the chainsaw sector is that of battery powered chainsaws that ultimately eliminate the impact of exhaust gases on humans and the environment. Today they represent a large share of the chain saw market. Their advantages include, in addition to eliminating exhaust gases, their lower weight as well as less vibration and noise during operation, compared to conventional saws (Colantoni et al. 2016).

Also another alternative for the use of a chainsaw without any environmental impact is that of electric chain saws. Of course, however, they can mainly be used for home use because they require a power supply. They could, however, be used in house firewood operations. In the market, electric chainsaws can be found under 
specifications of $45 \mathrm{~cm}$ length and a power of $2.5 \mathrm{KW}$ which are capable of most wood cutting operations, whereas lithium-ion chainsaws can be used in tree trunks and tree treatments as well as part-time at farm operations (Colantoni et al. 2016).

For chainsaws using alternative energy sources, such as the electric and the battery chainsaws, the average acceleration is lower than the one measured in the endothermic chainsaws (Neri et al. 2018; Poje et al. 2018). This results in added value of the former chainsaws, since that in general in the endothermic chainsaws the increase in exhaust emissions is influenced by the use of rich fuel mixtures (Wójcik \& Skarzyński 2006).

In the present study it was shown that the increase in $\mathrm{CO}$ emissions (Figure 4) during intense use of acceleration affects all chainsaws, but mainly the catalytic and semi-professional chainsaws. Also, it has been shown that in the professional chainsaw case, emissions in $\mathrm{NO}_{2}$ are increased for the same reasons as above (Figure 4). Most of research on the endothermic chainsaw emissions concentrate on $\mathrm{CO}$ and hydrocarbons emissions and are less focused on $\mathrm{NO}_{2}$ emissions. Wójcik \& Skarżyński (2006) report an increase in CO for endothermic chainsaws of approximately 7-8\%, which can reach up to $8-9 \%$ with frequent acceleration operation. The highest proportion of CO in this case according to Wójcik \& Skarżyński (2006) is due to the reduced amount of oxygen in the gas-fuel mixture.

The reduction of $\mathrm{CO}$ exhaust emissions, besides the controlled use of acceleration, can be achieved by introducing a proper adjustment of the chain saw carburetor (Emmerich \& Burger 1993; Róński \& Jabłoński; Wójcik 2003). Wójcik \& Skarżyński (2006) also report the positive effects of the clean filter on the reduction of $\mathrm{CO}$ emissions, which has been also verified by the present study (Figure 4).

An equally important source of exhaust gases is through the fuel vapor from the carburetor, i.e. the fuel tank, resulting from leakages of the fuel system into the atmosphere and subsequently the creation of nitrogen compounds (nitrates, aldehydes, peroxides and ozone) when combined with atmospheric oxygen, contributing thus to the creation of the photochemical cloud (see, e.g., Różański \& Jabloński 2001).

The adverse effect of fumes can be reduced by the use of special fuels, free of polycyclic hydrocarbons, such as the Alkylate fuel (Wójcik \& Skarżyński 2006). In the present work, Alkylate fuels have not been examined because they are generally not used in Greece, however according to the authors' opinion, the focus in Greece 
both with regard to research efforts as well as in practice, must concentrate towards a shift to Alkylate fuel.

According to Neri et al. (2018) there were statistically significant differences in the inhalation exposure to exhaust gas (PAHs) and BTEX (i.e. benzene, toluene, ethylbenzene and total xylenes) when using different fuel types. The exposure according to Neri et al. (2018) due to inhalation in PAHs and BTEX was generally lower when using modern alkylate fuels as compared to the traditional oil and leadfree petrol mixture.

\section{Conclusions}

\section{The professional chainsaw}

Generally speaking, a professional saw causes lower $\mathrm{CO}$ emissions than a catalytic saw and higher $\mathrm{CO}$ concentrations in comparison with an amateur saw under normal operating conditions and frequent accelerator use (Fig. 4b). The catalyst saw under the acceleration operation has been shown to produce high $\mathrm{CO}$ emissions. With regard to $\mathrm{NO}_{2}$ emissions, the amounts that it generates are generally less than the catalytic and slightly higher than the amateur saw (Figure 5b).

\section{The catalytic chainsaw}

The catalytic chainsaw generates the highest amounts of $\mathrm{NO}_{2}$ emissions (Figure 5b). CO concentrations are also higher in comparison with the professional and amateur saws. When the catalytic saw is operated with frequent accelerator use, it releases higher amounts of $\mathrm{CO}$ than the other two saws. However, when it is used with impure filters it produces less CO than the other two saws, a value which, nevertheless, is fairly high (Figure $4 b$ ).

\section{The amateur chainsaw}

Releases approximately the same amounts of $\mathrm{NO}_{2}$ gases (Figure 5b) as a professional saw. $\mathrm{CO}$ concentrations are relatively low when the saw is operated with frequent accelerator use. Bad quality oils and impure filters considerably affect its performance (Figure $4 b$ ).

Gas emissions can be reduced by applying special fuels without polycyclic hydrocarbons or introducing a suitable regulation of the chain saw carburetor. This would facilitates the reduction of CO emission (Emmerich \& Burger 1993; Różański \& Jabloński 2001; Wójcik 2002). 
The amateur chainsaw has proved to be safer and less harmful to the environment in terms of $\mathrm{NO}_{2}$ emissions however, the use of low quality oils is not recommended as it results in higher $\mathrm{NO}_{2}$ concentrations. On the other hand, a professional saw is less harmful as far as $\mathrm{CO}$ emissions are concerned. Finally, the catalytic saw emitted the highest concentrations of $\mathrm{NO}_{2}$, when used under an accelerated operation.

The use of low quality oils is the factor that most significantly affects the emission of the pollutants under investigation regardless of the type of chainsaw. The second most important factor that determines CO concentrations for all three saw types is the use of impure filters. The operation of the chainsaw with frequent accelerator use is affected by the saw type with the catalytic saw producing the highest $\mathrm{CO}$ concentrations (Figure $4 \mathrm{~b}$ ).

According to the results of this study, the use of a conventional chainsaw is highly recommended. Modern amateur saws have excellent performance; but they cannot be compared with professional ones, since they are considered less userfriendly and less environmentally friendly as they release higher amounts of emissions when used with impure filters.

For all three chainsaw types used and under all the operating conditions, the results show excess of the $\mathrm{CO}$ Time-Weighted Average Permissible Exposure Limit (50 ppm), which was also seen in the study by Leszczyniski (2014). The amateur chainsaw produces the lowest $\mathrm{CO}$ emissions under all operating conditions except when operated with frequent accelerator use.

The results that the use of the catalytic saw is not found to be more effective in relation to the release of $\mathrm{CO}$ and $\mathrm{NO}_{2}$ pollutants are in agreement with another study by Dimou et al. (2018) clearly show. When the professional saw is used, its maintenance and way of operation are of paramount importance. This means that its filter should be frequently cleaned according to the manufacturer specifications and recommended using oils; low quality oils must be avoided (Dimou et al. 2018).

The wind variation accounts for much of the wide variation in measured concentrations at the breathing zone samplers. In the absence of other information it could be assumed that still air would result in the highest breathing zone concentrations. Nilsson et al. (1987) comment that their survey of operators showed that the worst subjective symptoms of exposure were associated with thick forest, calm weather and deep snow. 
According to the work by Wójcik and Skarżyński (2006), the threat caused by $\mathrm{CO}$ can be multiplied by: unfavorable wind direction and speed, as well as its lack, local conditions, compaction of the stand, chainsaw poor technical conditions, usage of too rich fuel mixtures, and the maladjustment of the carburetor.

The outcomes of the present study can be of use on giving guidance on the use of greener chainsaw operations for reducing hazardous emissions to the atmosphere during logging operations.

\section{References}

Athanassiadis D. 2000. Energy consumption and exhaust emissions in mechanized timber harvesting operations in Sweden. Science of the Total Environment, 255(1-3): 135-43, http://dx.doi. org/10.1016/S0048-9697(00)00463-0.

Colantoni A, Mazzocchi F, Cossio F, Cecchini M, Bedini R, Monarca D (2016) Comparisons between Battery Chainsaws and Internal Combustion Engine Chainsaws: Performance and Safety. Contemporary Engineering Sciences, 27(9): 1315-1337. doi.org/10.12988/ces.2016.68133.

Daikou A, Dontas S. 2013 Threshold Limit Values of Exposure to Chemical Substances \& Biological Exposure Indices to Chemical Agents. Greek Legislation, ACGIH, DFG. Hellenic Institute for Occupational Health and Safety (In Greek).

Dimou V, Anezakis VD, Demertzis K, Iliadis L. 2018. Comparative analysis of exhaust emissions caused by chainsaws. Int. J. Environ. Sci. Technol. 15(7): 15971608 .

Dobson AJ, Barnett A. 2008. An Introduction to Generalized Linear Models. CRC press.

Emmerich W, Burger W. 1993. Minderung der Schadstoffemission bei handgeführten Motorgeräten, Der Wald Berlin 43.

Galante MV, Dutschke M, Patenaude G, Vickers B. 2012. Climate change mitigation through reduced-impact logging and the hierarchy of production forest management, Forests, 3: 59-74.

Gentekakis IB. 2003. Atmospheric Pollution. Consequences, Control and Alternative Technologies. Tziola (In Greek).

Hellenic National Meteorological Service (H.N.M.S). Climate report, September 2018. Available at: http://www.hnms.gr/emy/el/climatology/climatology_month 
Keenan RJ, Nitschke C. 2016. Forest management options for adaptation to climate change: a case study of tall, wet eucalypt forests in Victoria's Central Highlands region. Australian Forestry, 79(2): 96-107.

Komuński P. 1995. Banania emisji tlenku wegla podczas pracy pilara [Research of the issue of the carbon monoxide during the work chain saw. The doctoral thesis]. Maszyn. Pr. Dokt. Kulid ar Kraków [in Polish].

Lambert D. 1992. Zero-inflated Poisson regression, with an application to defects in manufacturing. Technometrics, 34: 1-14.

Leszczyn்ski K. 2014. The Concentration of Carbon Monoxide in the breathing areas of workers during logging operations at the motor-manuell level. International Journal of Occupational Medicine and Environmental Health, 27(5): 821-829. http://dx.doi.org/10.2478/s13382-014-0300-x.

Lijewski P, Merkisz JFP. 2013. Research of exhaust emissions from a harvester diesel engine with the use of portable emission measurement system. Croatian Journal of Forest Engineering. [cited 2013 Oct 15]; 34(1): 113-23. Available from: http://www.crojfe. com/r/i/lijewski_113-122.pdf.

Magagnotti N, Picchi G, Sciarra G, Spinelli R. 2014. Exposure of mobile chipper operators to diesel exhaust. Annals of Occupational Hygiene, 58(2): 217-226, http://dx.doi.org/10.1093/annhyg/met059.

Malesios C, Demiris N, Abas Z, Dadousis K, Koutroumanidis T. 2014. Modelling Sheep pox Disease from the 1994- 1998 Epidemic in Evros Prefecture, Greece. Spatial and Spatio-temporal Epidemiology, 11: 1-10.

Merkisz J, Lijewski P. 2010. Time Density of Engine Operation in Non-road Vehicles in the Aspect of the Homologation Toxic Emission Test. SAE Paper 2010-01-1282 Walsh, M., 2011: Global trends in motor vehicle control: a 2011update. Combustion engines, 50(2): 106-117.

Neri F, Laschi An, Foderi C, Fabiano F, Bertuzzi L, Marchi En. 2018. Determining Noise and Vibration Exposure in Conifer Cross-Cutting Operations by Using Li-Ion Batteries and Electric Chainsaws. Forests, 9, doi:10.3390/f9080501.

Nilsson CA, Lindahl R, Norstrom A. 1987. Occupational exposure to chain saw exhausts in logging operations. American Industrial Hygiene Association Journal, 48: 99-105.

Ojima J. 2012. Gaseous Contaminant Distribution in the Breathing Zone. Industrial Health, 50: 236-238.

Poje A, Poto cnik I, Miheli`c M. 2018. Comparison of Electric and Petrol Chainsaws in Terms of Efficiency and Safety When Used in Young Spruce Stands in Small-Scale Private Forests. Small-Scale Forestry, 1-12. 
Różański H, Jabloński K. 2001. Yagrożenia operatorów emisją z dwusuwowych silników spalinowych [Threats of operators with the issue of gases from two-stroke explosion engines], PTRiL 1 [in Polish].

Ruth-Sahd LA, Zulkosky K, Fetter ME. 2011. Carbon monoxide poisoning: Case studies and review. Dimensions of Critical Care Nursing, 30: 303-314, http://dx.doi.org/10.1097/DCC. 0b013e31822fb017.R.

Slaughter JC, Koenig JQ, Reinhardt TE. 2004. Association between lung function and exposure to smoke among frefght ers at prescribed burns. Journal of Occupational and Environmental Hygiene, 1(1): 45-49, http://dx.doi.org/10.1080/15459620490264490.

Sonnleitner G. 1992. Bio-Motorsägenkettenöle in der Forstwirtschaft. Österreichische Forstzeitung 4, 39.

Sowa J, Leszczyński K. 2005. Emission of carbon monoxide during work with a power chain saw and cable winch propelled by a chain saw engine. In: Sowa J, Barszcz J, Sosnowski A, editors. International Scientifc Conference "Ecological, Ergonomic and Economical Optimization of Forest Utilization in Sustainable Forest Management"; June 15-18.

Walsh M. 2011. Global trends in motor vehicle control: a 2011 update. Combustion engines, 50(2): 106-117.

Wójcik K, Skarżyński JG. 2006. Emission and composition of exhaust gases by new chain saws produced by Husqvarna and Stihl. Acta Sc. Pol. Silv. Colendar. Rat. Ind. Lignar. 5(2): 147-157.

Wójcik K. 2002. Analiza podstawowych parametrów pilarek spalinowych na rynku europejskim [The analysis of basic parameters of chain saw on Euromarket]. PTRiL 10 [in Polish].

World Bank Group. 1998. Pollution Prevention and Abatement Handbook. The World Bank Group in collaboration with the United Nations Environment Programme and the United Nations Industrial Development Organization. 


\section{APPENDIX}

Table A1. Descriptive statistics for the $\mathrm{CO}$ and $\mathrm{NO}_{2}$ concentrations, broken down by chainsaw and operation type

\begin{tabular}{llcccccc}
\hline $\begin{array}{l}\text { Measured } \\
\text { gases(ppm) }\end{array}$ & Min. & Max. & Mean & $\begin{array}{c}\text { media } \\
\mathbf{n}\end{array}$ & $\begin{array}{c}\text { Std. } \\
\text { Deviatio } \\
\text { n }\end{array}$ & N \\
\hline CO & catalyst & 6 & 1238 & 152.43 & 107 & 161.49 & 204 \\
& professional & 6 & 285 & 114.75 & 85 & 107.18 & 274 \\
& amateur & 0 & 1860 & 143.70 & 60 & 248.09 & 277 \\
\hline & witness & 6 & 1238 & 88.23 & 59 & 112.21 & 204 \\
& acceleration & 0 & 690 & 107.18 & 58 & 123.45 & 205 \\
& oil & 6 & 1860 & 221.69 & 144 & 275.42 & 209 \\
& filter & 6 & 585 & 117.05 & 74 & 119.74 & 137 \\
\hline $\mathbf{N O}_{2}$ & catalyst & 0 & 380 & 18.57 & 0.1 & 55.12 & 338 \\
& professional & 0 & 0.3 & 0.06 & 0 & 0.104 & 274 \\
& amateur & 0 & 0.4 & 0.03 & 0 & 0.082 & 277 \\
\hline & witness & 0 & 0.3 & 0.07 & 0 & 0.101 & 204 \\
& acceleration & 0 & 0.3 & 0.06 & 0 & 0.095 & 205 \\
& oil & 0 & 0.4 & 0.04 & 0 & 0.091 & 209 \\
& filter & 0 & 380 & 23.13 & 0 & 60.71 & 271 \\
\hline
\end{tabular}

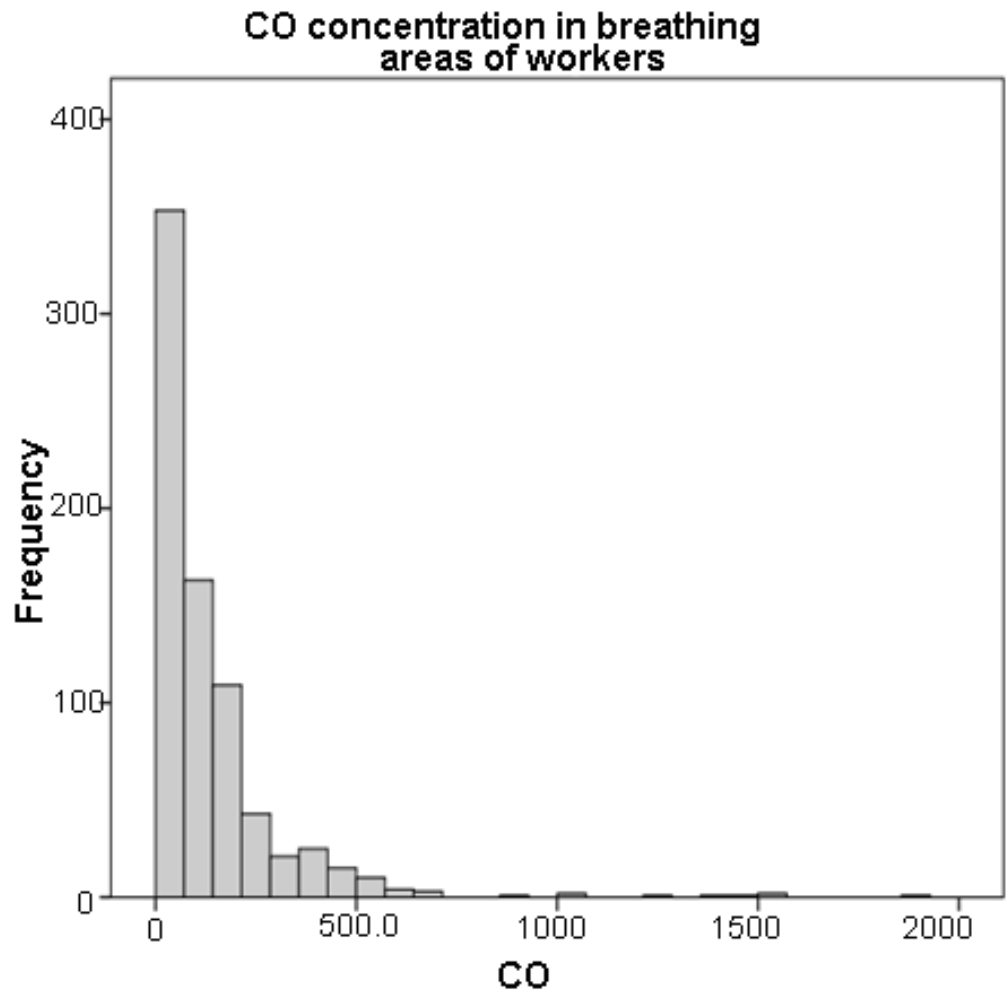

Figure A1. Histogram of $\mathrm{CO}$ concentration in breathing areas of workers during logging operations 


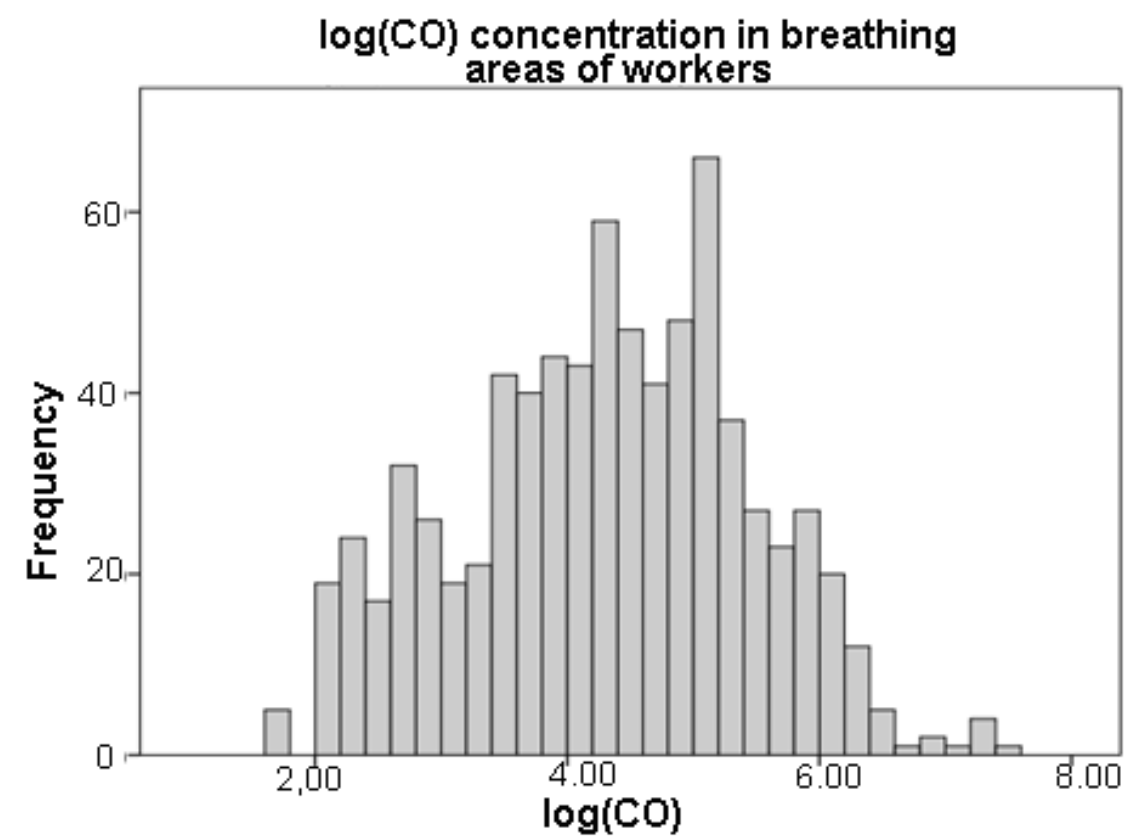

Figure A2. Histogram of $\log (\mathrm{CO})$ in breathing areas of workers during logging operations

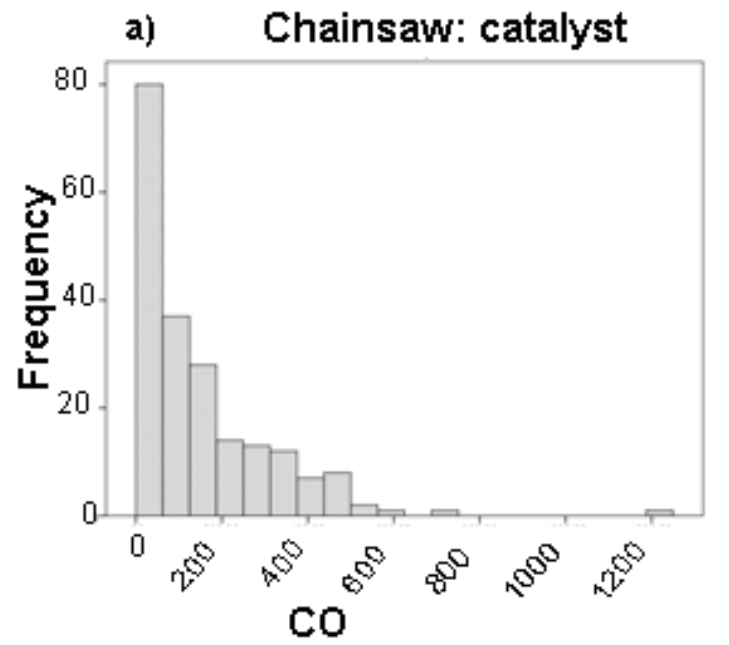

b) Chainsaw: professional

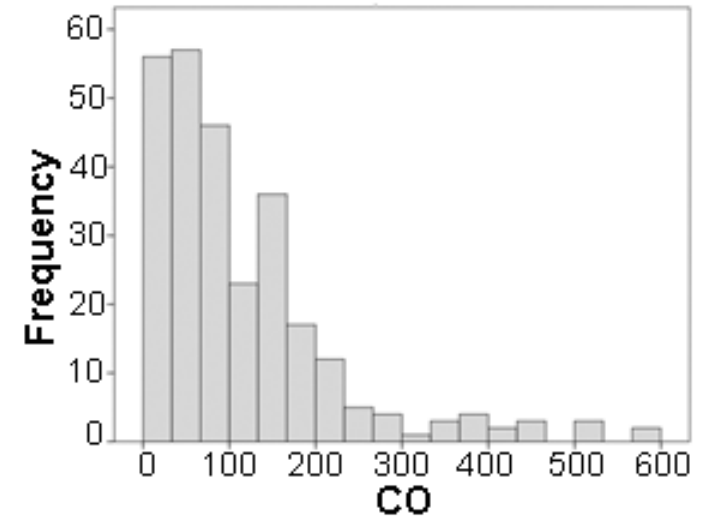

c) Chainsaw: amateur

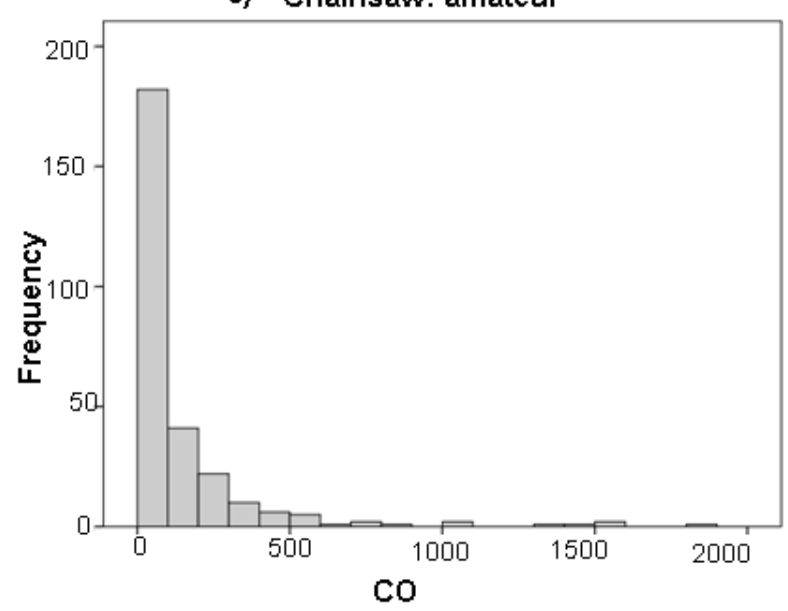

Figure A3. Histogram of $\mathrm{CO}(\mathrm{ppm})$ concentration in breathing areas of workers by type of chainsaw 
a) Operation type:witness

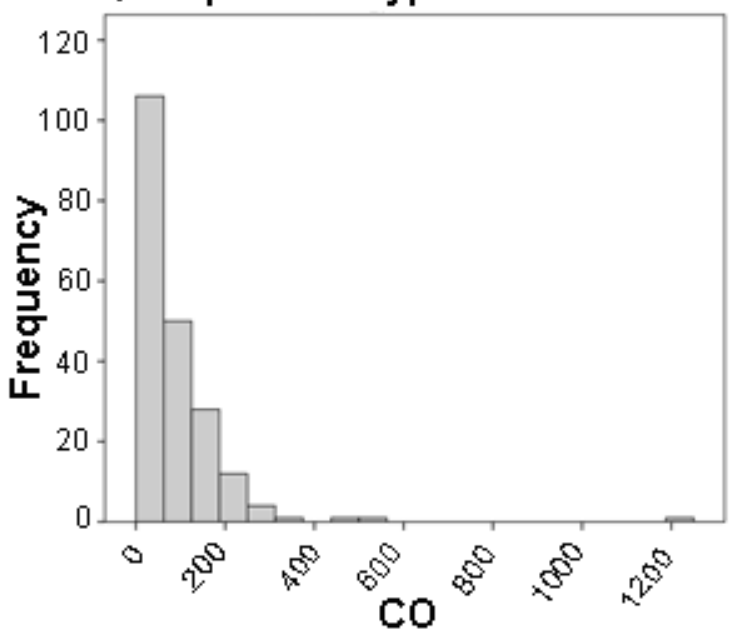

c) Operation type:oil

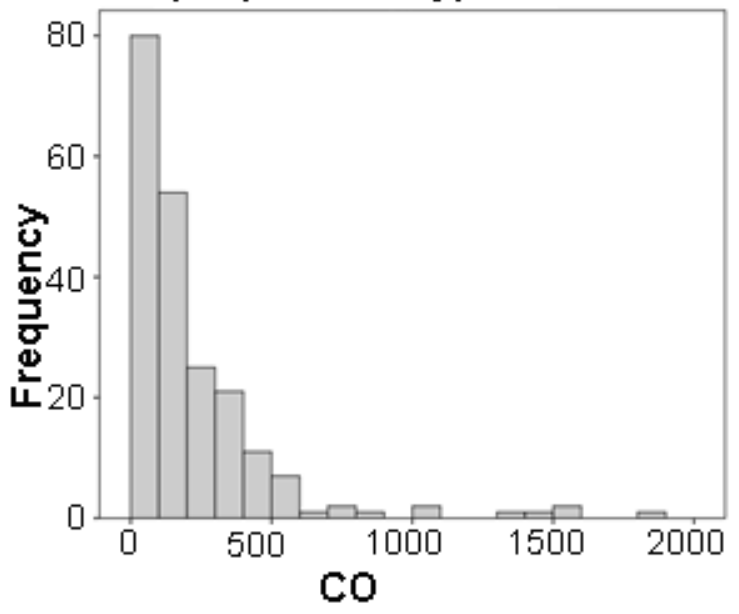

b) Operation type:acceleration

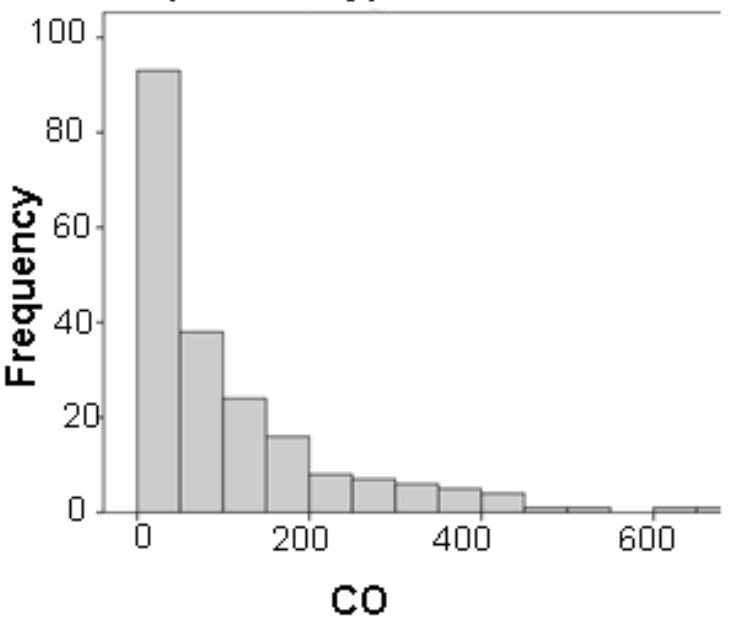

d) Operation type:filter

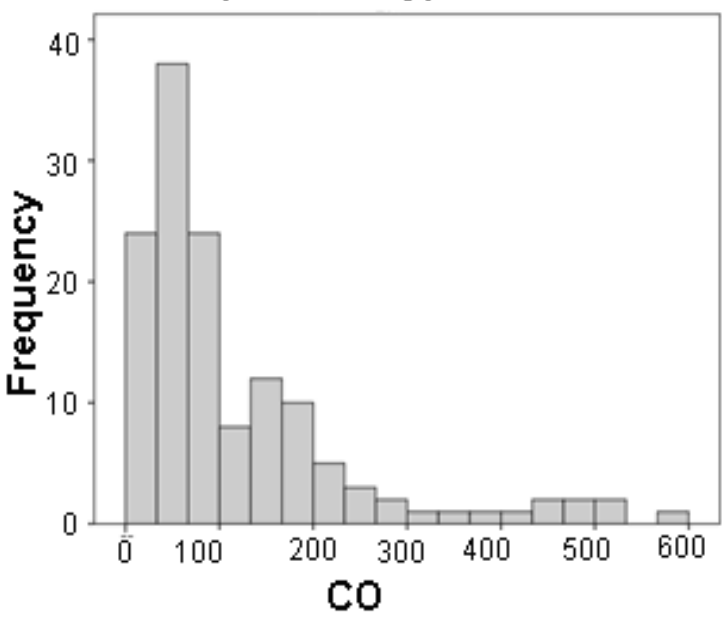

Figure A4. Histogram of $\mathrm{CO}$ (ppm) concentration in breathing areas of workers by type of operation

Table A2. Subsets derived from Post-hoc test of Scheffe by chainsaw type

\begin{tabular}{|l|l|c|c|}
\hline \multirow{2}{*}{$\begin{array}{l}\text { Post-hoc } \\
\text { test }\end{array}$} & \multirow{2}{*}{$\begin{array}{l}\text { Chainsaw } \\
\text { type }\end{array}$} & \multicolumn{2}{|c|}{ Subset } \\
\cline { 3 - 4 } & amateur & 4.183 & $\mathbf{2}$ \\
\hline \multirow{3}{*}{ Scheffe } & professional & 4.319 & 4.319 \\
\cline { 2 - 4 } & catalyst & & 4.433 \\
\hline
\end{tabular}

Table A3. Subsets derived from Post-hoc test of Scheffe by operation type

\begin{tabular}{|l|l|l|l|}
\hline Post-hoc & \multirow{2}{*}{$\begin{array}{c}|c| \\
\text { test }\end{array}$} & Operation_type & \multicolumn{2}{|c|}{ Subset } \\
\hline Scheffe & witness & 4.000 & 2 \\
\cline { 2 - 4 } & acceleration & 4.071 & \\
\cline { 2 - 4 } & & 4.282 & \\
\cline { 2 - 4 } & filter & & 4.831 \\
\cline { 2 - 4 } & oil & &
\end{tabular}


Table 1. Characteristics of the chainsaws used in the study

\begin{tabular}{|c|c|c|c|c|c|c|}
\hline \multirow[t]{2}{*}{ Brand } & \multirow[t]{2}{*}{ Model } & \multirow{2}{*}{$\begin{array}{l}\text { Engine } \\
\text { size }\left(\mathrm{cm}^{3}\right)\end{array}$} & \multirow{2}{*}{$\begin{array}{l}\text { Power } \\
\text { (KW/CV) }\end{array}$} & \multicolumn{2}{|c|}{ Capacity (l) } & \multirow{2}{*}{$\begin{array}{l}\text { Weight } \\
\text { (empty KG) }\end{array}$} \\
\hline & & & & $\begin{array}{l}\text { Tank } \\
\text { volume }\end{array}$ & $\begin{array}{l}\text { Oil Tank } \\
\text { volume }\end{array}$ & \\
\hline Stihl & MS 361 & 59.0 & $3.4 / 4.6$ & 0.68 & 0.325 & 5.6 \\
\hline Stihl & MS 170 & 30.1 & $1.2 / 1.6$ & 0.25 & 0.145 & 4.1 \\
\hline Stihl & D 170 & 30.1 & $1.2 / 1.6$ & 0.25 & 0.145 & 4.2 \\
\hline
\end{tabular}
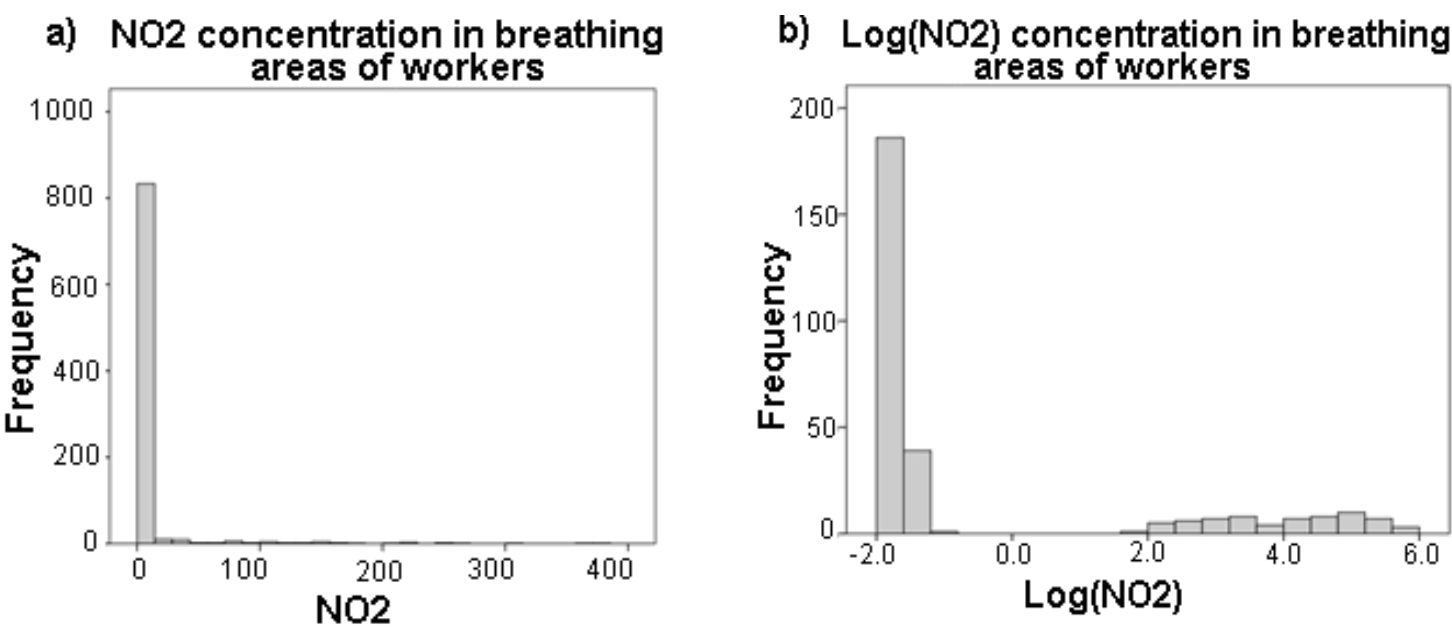

Figure A5. Histogram of $\mathrm{NO}_{2}(\mathrm{ppm})$ and $\log \left(\mathrm{NO}_{2}\right)$ concentration in breathing areas of workers during logging operations 
Table 2. Measurement conditions of $\left(\mathrm{Y}_{1}=\mathrm{CO}\right)$ and $\left(\mathrm{Y}_{2}=\mathrm{NO}_{2}\right)$ emissions produced by a professional, a catalytic and an amateur chainsaw

Type of chainsaw

\begin{tabular}{|c|c|c|c|}
\hline $\begin{array}{l}\text { Operating } \\
\text { parameters }\end{array}$ & Professional & $X_{2}=$ Catalytic & $X_{3}=$ Amateur \\
\hline $\begin{array}{l}X^{\prime}{ }_{1}=\text { Normal } \\
\text { conditions }\end{array}$ & $\begin{array}{l}\mathrm{XX}_{1,1}^{\prime}=\text { Professional } \\
\text { under normal conditions }\end{array}$ & $\begin{array}{l}\mathrm{XX}_{2,1}^{\prime}=\text { Catalytic under } \\
\text { normal conditions }\end{array}$ & $\begin{array}{l}\mathrm{XX}_{3,1}^{\prime}=\text { Amateur under } \\
\text { normal conditions }\end{array}$ \\
\hline $\begin{array}{l}X_{2}^{\prime}=\text { Frequent } \\
\text { accelerator }\end{array}$ & $\begin{array}{l}\mathrm{XX}^{\prime}{ }_{1,2}=\text { Professional } \\
\text { with frequent accelerator }\end{array}$ & $\begin{array}{l}\mathrm{XX}_{2,2}^{\prime}=\text { Catalytic with } \\
\text { frequent accelerator }\end{array}$ & $\begin{array}{l}\mathrm{XX}_{3,2}^{\prime}=\text { Amateur with } \\
\text { frequent accelerator }\end{array}$ \\
\hline$X_{3}^{\prime}=$ Poor quality oils & $\begin{array}{l}\mathrm{XX}_{1,3}^{\prime}=\text { Professional } \\
\text { with poor quality oil }\end{array}$ & $\begin{array}{l}\mathrm{XX}_{2,3}^{\prime}=\text { Catalytic with } \\
\text { poor quality oil }\end{array}$ & $\begin{array}{l}\mathrm{XX}_{3,3}^{\prime}=\text { Amateur with } \\
\text { poor quality oil }\end{array}$ \\
\hline$X^{\prime}{ }_{4}=$ Impure filter & $\begin{array}{l}\mathrm{XX}_{1,4}^{\prime}=\text { Professional } \\
\text { with impure filter }\end{array}$ & $\begin{array}{l}\mathrm{XX}_{2,4}^{\prime}=\text { Catalytic with } \\
\text { impure filter }\end{array}$ & $\begin{array}{l}\mathrm{XX}_{3,4}^{\prime}=\text { Amateur with } \\
\text { impure filter }\end{array}$ \\
\hline
\end{tabular}

Total measurements $Y_{I}=C O: 755$

Total measurements $\mathrm{Y}_{2}=\mathrm{NO}_{2}: 892$ 
Table 3. Descriptive statistics for the $\mathrm{CO}$ and $\mathrm{NO}_{2}$ concentration (ppm) in breathing areas during logging operations

\begin{tabular}{lccccc}
\hline $\begin{array}{l}\text { Measured } \\
\text { gases } \\
(\mathbf{p p m})\end{array}$ & Minimum & Maximum & Mean & $\begin{array}{c}\text { Std. } \\
\text { Deviation }\end{array}$ & $\mathbf{N}$ \\
\hline CO & 0 & 1860 & 135.55 & 184.31 & 755 \\
NO $_{2}$ & 0 & 380 & 7.09 & 35.13 & 892 \\
\hline
\end{tabular}


Table 4. Post-hoc tests from Analysis of variance for the differences between chainsaw types for $\log (\mathrm{CO})$ concentration

\begin{tabular}{|c|c|c|c|c|c|c|}
\hline \multirow{3}{*}{$\begin{array}{l}\text { Post Hoc } \\
\text { test } \\
\text { Scheffe }\end{array}$} & \multirow{2}{*}{\multicolumn{2}{|c|}{ Chainsaw type }} & \multirow{3}{*}{$\begin{array}{c}\begin{array}{c}\text { Mean } \\
\text { Difference }\end{array} \\
0.114\end{array}$} & \multirow{3}{*}{$\frac{\text { p-value }}{\text { n.s. }}$} & \multicolumn{2}{|c|}{$\mathbf{9 5 \%}$ Confidence Interval } \\
\hline & & & & & \multirow{2}{*}{$\begin{array}{c}\begin{array}{l}\text { Lower } \\
\text { Bound }\end{array} \\
-0.131 \\
\end{array}$} & \multirow{2}{*}{$\begin{array}{c}\begin{array}{c}\text { Upper } \\
\text { Bound }\end{array} \\
0.358\end{array}$} \\
\hline & \multirow{2}{*}{$\begin{array}{l}\text { Chainsaw ty } \\
\text { catalyst }\end{array}$} & professional & & & & \\
\hline & & amateur & $0.249^{*}$ & 0.043 & 0.006 & 0.494 \\
\hline & \multirow[t]{2}{*}{ professional } & catalyst & -0.114 & n.s. & -0.358 & 0.131 \\
\hline & & amateur & 0.136 & n.s. & -0.089 & 0.362 \\
\hline & \multirow[t]{2}{*}{ amateur } & catalyst & $-0.249^{*}$ & 0.043 & -0.494 & -0.006 \\
\hline & & professional & -0.136 & n.s. & -0.362 & 0.089 \\
\hline \multirow[t]{6}{*}{ LSD } & \multirow[t]{2}{*}{ catalyst } & professional & 0.114 & n.s. & -0.082 & 0.309 \\
\hline & & amateur & $0.249^{*}$ & 0.012 & 0.054 & 0.445 \\
\hline & \multirow[t]{2}{*}{ professional } & catalyst & -0.114 & n.s. & -0.309 & 0.082 \\
\hline & & amateur & 0.136 & n.s. & -0.044 & 0.317 \\
\hline & \multirow[t]{2}{*}{ amateur } & catalyst & $-0.249^{*}$ & 0.012 & -0.445 & -0.054 \\
\hline & & professional & -0.136 & n.s. & -0.317 & 0.044 \\
\hline \multirow[t]{6}{*}{ Bonferroni } & \multirow[t]{2}{*}{ catalyst } & professional & 0.114 & n.s. & -0.125 & 0.353 \\
\hline & & amateur & $0.249^{*}$ & 0.037 & 0.011 & 0.489 \\
\hline & \multirow[t]{2}{*}{ professional } & catalyst & -0.114 & n.s. & -0.353 & 0.125 \\
\hline & & amateur & 0.136 & n.s. & -0.084 & 0.357 \\
\hline & \multirow[t]{2}{*}{ amateur } & catalyst & $-0.249^{*}$ & 0.037 & -0.489 & -0.011 \\
\hline & & professional & -0.136 & n.s. & -0.357 & 0.084 \\
\hline
\end{tabular}

n.s.: non-significant; *significant at the 5\% significance level 
Table 5. Post-Hoc tests from Analysis of variance for the differences between operation types for $\log (\mathrm{CO})$ concentration

\begin{tabular}{|c|c|c|c|c|c|c|}
\hline \multirow[b]{2}{*}{ Post Hoc test } & \multirow{2}{*}{\multicolumn{2}{|c|}{ Operation type }} & \multirow[b]{2}{*}{$\begin{array}{c}\text { Mean } \\
\text { Difference }\end{array}$} & \multirow[b]{2}{*}{ p-value } & \multicolumn{2}{|c|}{$\begin{array}{c}\text { 95\% Confidence } \\
\text { Interval }\end{array}$} \\
\hline & & & & & $\begin{array}{l}\text { Lower } \\
\text { Bound }\end{array}$ & $\begin{array}{l}\text { Upper } \\
\text { Bound }\end{array}$ \\
\hline \multirow[t]{12}{*}{ Scheffe } & \multirow[t]{3}{*}{ witness } & acceleration & -0.070 & n.s. & -0.369 & 0.228 \\
\hline & & oil & $-0.830^{*}$ & $<0.001$ & -1.127 & -0.533 \\
\hline & & filter & -0.282 & n.s. & -0.615 & 0.051 \\
\hline & \multirow[t]{3}{*}{ acceleration } & witness & 0.070 & n.s. & -0.228 & 0.369 \\
\hline & & oil & $-0.760^{*}$ & $<0.001$ & -1.057 & -0.462 \\
\hline & & filter & -0.211 & n.s. & -0.545 & 0.122 \\
\hline & \multirow[t]{3}{*}{ oil } & witness & $0.830^{*}$ & $<0.001$ & 0.533 & 1.127 \\
\hline & & acceleration & $0.760^{*}$ & $<0.001$ & 0.462 & 1.057 \\
\hline & & filter & $0.548^{*}$ & $<0.001$ & 0.216 & 0.880 \\
\hline & \multirow[t]{3}{*}{ filter } & witness & 0.282 & n.s. & -0.051 & 0.615 \\
\hline & & acceleration & 0.211 & n.s. & -0.122 & 0.545 \\
\hline & & oil & $-0.548^{*}$ & $<0.001$ & -0.880 & -0.216 \\
\hline \multirow[t]{12}{*}{ LSD } & \multirow[t]{3}{*}{ witness } & acceleration & -0.070 & n.s. & -0.280 & 0.139 \\
\hline & & oil & $-0.830^{*}$ & $<0.001$ & -1.038 & -0.622 \\
\hline & & filter & $-0.282^{*}$ & 0.018 & -0.515 & -0.048 \\
\hline & \multirow[t]{3}{*}{ acceleration } & witness & 0.070 & n.s. & -0.139 & 0.280 \\
\hline & & oil & $-0.760^{*}$ & $<0.001$ & -0.968 & -0.551 \\
\hline & & filter & -0.211 & n.s. & -0.445 & 0.022 \\
\hline & \multirow[t]{3}{*}{ oil } & witness & $0.830^{*}$ & $<0.001$ & 0.622 & 1.038 \\
\hline & & acceleration & $0.760^{*}$ & $<0.001$ & 0.551 & 0.968 \\
\hline & & filter & $0.548^{*}$ & $<0.001$ & 0.316 & 0.781 \\
\hline & \multirow[t]{3}{*}{ filter } & witness & $0.282^{*}$ & 0.018 & 0.048 & 0.515 \\
\hline & & acceleration & 0.211 & n.s. & -0.022 & 0.445 \\
\hline & & oil & $-0.548^{*}$ & $<0.001$ & -0.781 & -0.316 \\
\hline \multirow[t]{12}{*}{ Bonferroni } & \multirow[t]{3}{*}{ witness } & acceleration & -0.070 & n.s. & -0.352 & 0.212 \\
\hline & & oil & $-0.830^{*}$ & $<0.001$ & -1.110 & -0.549 \\
\hline & & filter & -0.281 & n.s. & -0.596 & 0.032 \\
\hline & \multirow[t]{3}{*}{ acceleration } & witness & 0.070 & n.s. & -0.212 & 0.352 \\
\hline & & oil & $-0.760^{*}$ & $<0.001$ & -1.040 & -0.479 \\
\hline & & filter & -0.211 & n.s. & -0.526 & 0.103 \\
\hline & \multirow[t]{3}{*}{ oil } & witness & $0.830^{*}$ & $<0.001$ & 0.549 & 1.110 \\
\hline & & acceleration & $0.760^{*}$ & $<0.001$ & 0.479 & 1.040 \\
\hline & & filter & $0.548^{*}$ & $<0.001$ & 0.235 & 0.861 \\
\hline & \multirow[t]{3}{*}{ filter } & witness & 0.281 & n.s. & -0.032 & 0.596 \\
\hline & & acceleration & 0.211 & n.s. & -0.103 & 0.526 \\
\hline & & oil & $-0.548^{*}$ & $<0.001$ & -0.861 & -0.235 \\
\hline
\end{tabular}

n.s.: non-significant; *significant at the 5\% significance level 
Table 6. Parameter estimates of the zero inflated regression model and corresponding significances

\begin{tabular}{|c|c|c|}
\hline Covariate & Median & p-value \\
\hline Constant & 15.47 & $<0.001$ \\
\hline \multicolumn{3}{|c|}{ Chainsaw type (reference category: amateur) } \\
\hline Catalyst & 15.39 & $<0.001$ \\
\hline Professional & -0.02 & n.s. \\
\hline \multicolumn{3}{|c|}{ Operation type (reference category: filter) } \\
\hline Witness & -20.45 & $<0.001$ \\
\hline Acceleration & -20.51 & $<0.001$ \\
\hline Oil & -20.43 & $<0.001$ \\
\hline deviance & 7,486 & \\
\hline
\end{tabular}

n.s.: non-significant 


\section{FIGURES}

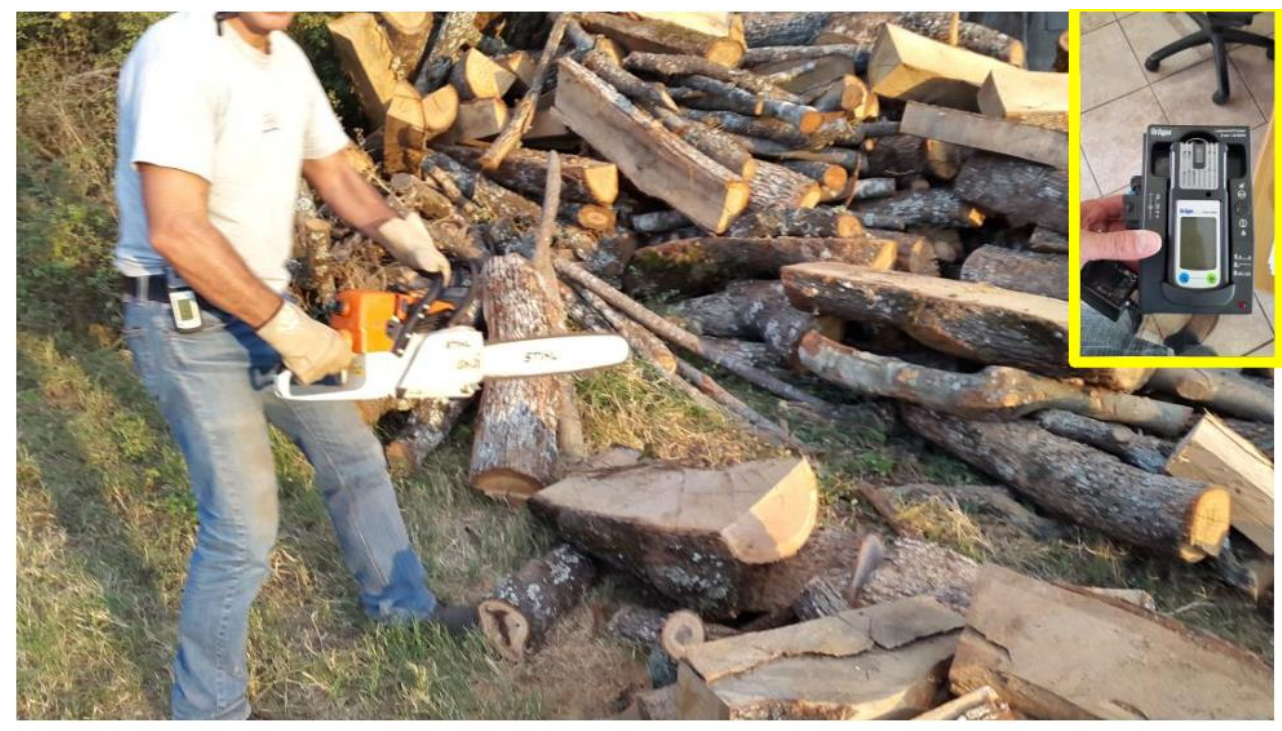

Figure 1
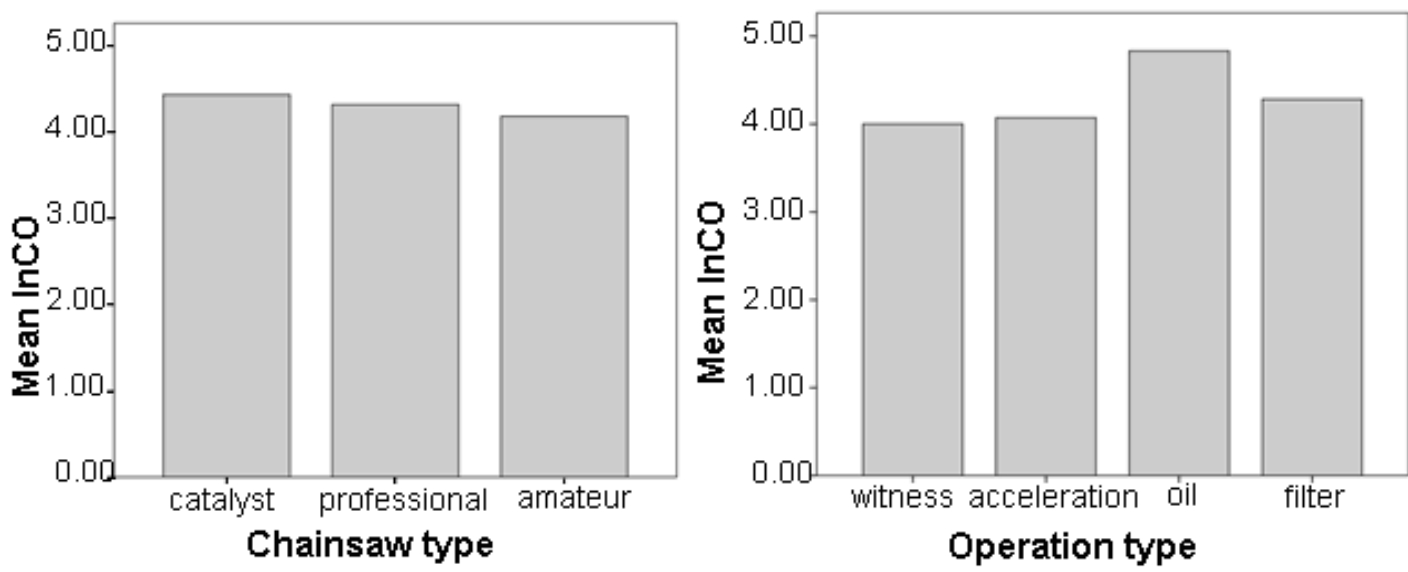

Figure 2
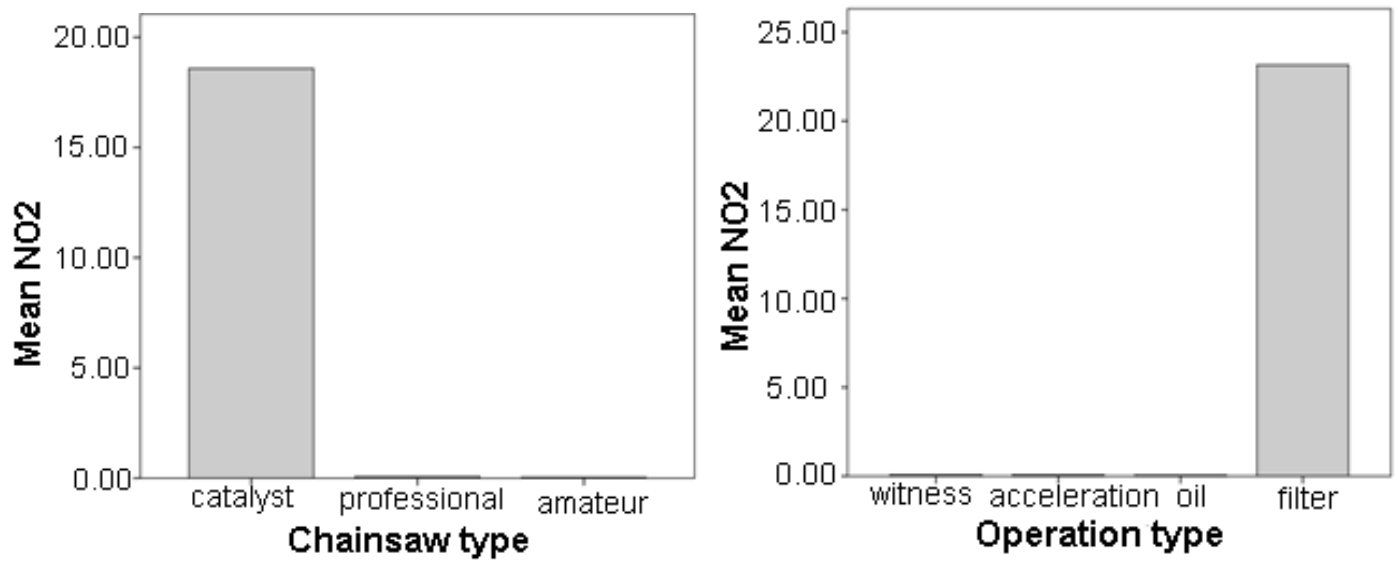

Figure 3 


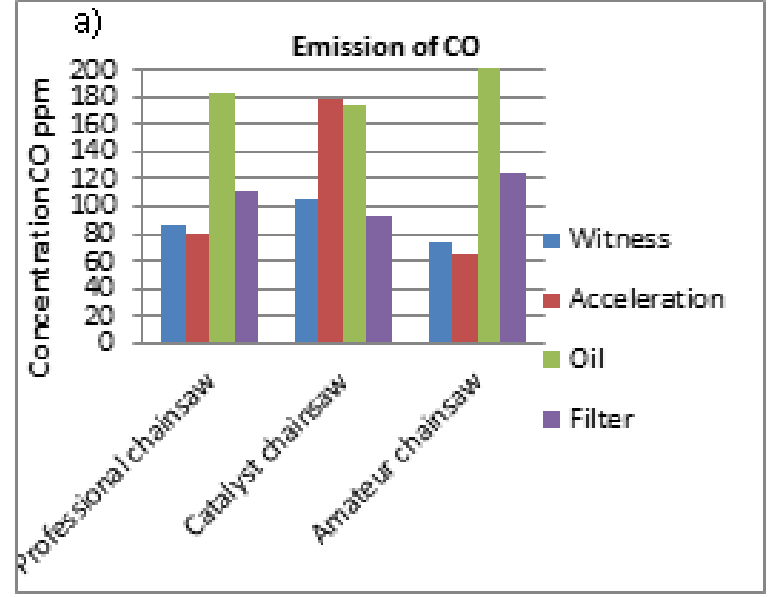

Figure 4a,b

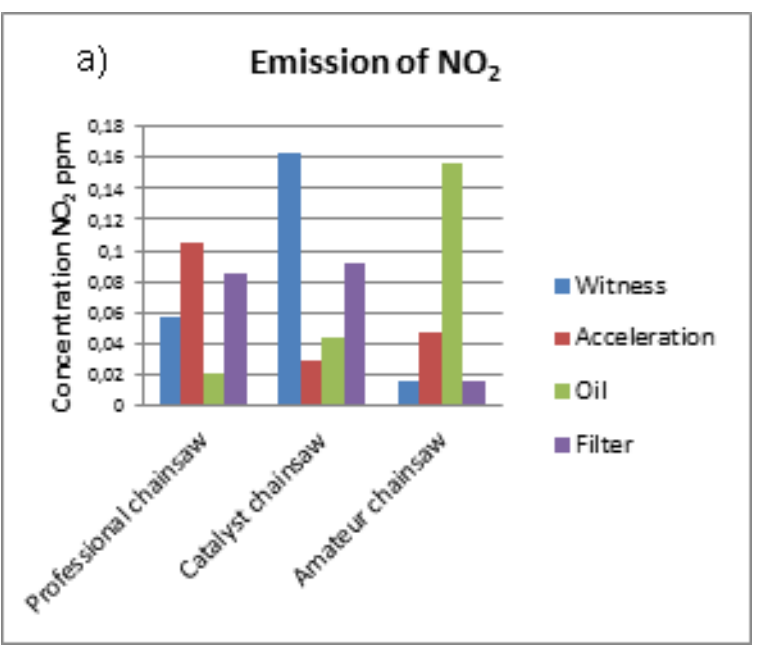

Figure 5a,b

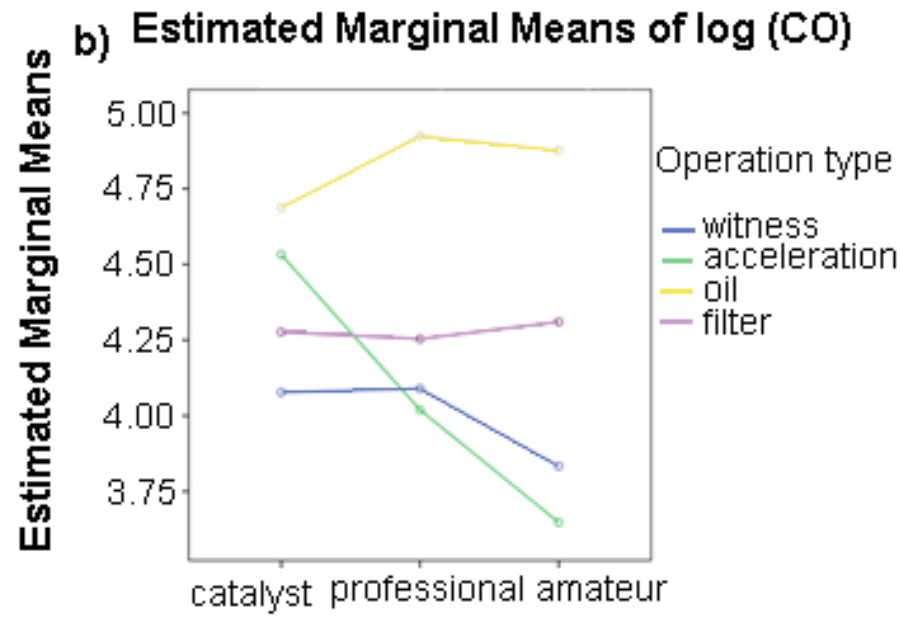

Chainsaw type b) Estimated Marginal Means of $\log (\mathrm{NO} 2)$

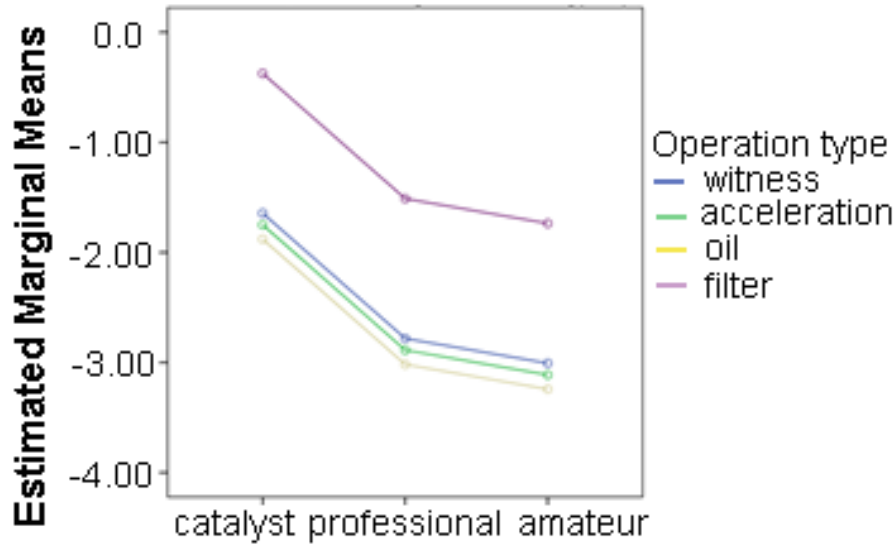

Chainsaw type 
Figure 1. Logging of Quercus petraea in an exposed yard

Figure 2. Bar chart of the average $\ln (\mathrm{CO})$ concentration (ppm) by type of chainsaw and operation

Figure 3. Bar chart of the average $\mathrm{NO}_{2}$ concentration (ppm) by type of chainsaw and operation

Figure 4 a,b. (a) Concentration of $\mathrm{CO}$ in ppm (a raw data values) by operation and chainsaw type (b) Line plot of average $\mathrm{CO}$ concentration by operation and chainsaw type (log-transformed values)

Figure 5 a,b. (a) Concentration of $\mathrm{NO}_{2}$ in ppm (a raw data values) by operation and chainsaw type (b) Line plot of average $\mathrm{NO}_{2}$ concentration by operation and chainsaw type (log-transformed values) 